\title{
Theorizing power in political ecology: the where of power in resource governance projects
}

\author{
Helene Ahlborg ${ }^{1}$ \\ Andrea J. Nightingale \\ University of Gothenburg and Chalmers University of Technology, Sweden \\ Swedish University of Agricultural Sciences, Sweden and Norwegian University of Life Sciences, Norway
}

\begin{abstract}
Power and politics have been central topics from the early days of Political Ecology. There are different and sometimes conflicting conceptualizations of power in this field that portray power alternatively as a resource, personal attribute or relation. The aim of this article is to contribute to theorizations of power by probing contesting views regarding its role in societal change and by presenting a specific conceptualization of power, one which draws on political ecology and sociotechnical approaches in science and technology studies. We review how power has been conceptualized in the political ecology field and identify three trends that shaped current discussions. We then develop our conceptual discussion and ask explicitly where power emerges in processes of resource governance projects. We identify four locations that we illustrate empirically through an example of rural electrification in Tanzania that aimed at catalyzing social and economic development by providing renewable energy-based electricity services. Our analysis supports the argument that power is relational and productive, and it draws on science and technology studies to bring to the fore the critical role of non-human elements in co-constitution of society - technology - nature. This leads us to see the exercise of power as having contradictory and ambiguous effects. We conclude that by exploring the tension between human agency and constitutive power, we keep the politics alive throughout the analysis and are able to show why intentional choices and actions really matter for how resource governance projects play out in everyday life.
\end{abstract}

Keywords: Power; political ecology; sociotechnical systems; renewable energy; Tanzania

\section{Résumé}

Le pouvoir et la politique ont été des sujets clés depuis les premiers jours de l'approche «political ecology». Il existe des conceptualisations différentes et parfois contradictoires du pouvoir dans ce domaine, qui représentent le pouvoir en tant que ressource, attribut personnel ou relation. Le but de cet article est de contribuer aux théorisations du pouvoir en sondant les points de vue contestants sur son rôle dans le changement sociétal et en présentant une conceptualisation spécifique du pouvoir. C’est une approche qui s’appuie sur «political ecology»

\footnotetext{
${ }^{1}$ Dr. Helene Ahlborg, postdoctoral research fellow, School of Global Studies, University of Gothenburg, Box 700, 405 30, Göteborg, Sweden. Email: helene.ahlborg "at" gu.se. During the writing of this article she was a post doc at Chalmers University of Technology, Division of Environmental Systems Analysis, Chalmers University of Technology, 41296 Göteborg, Sweden funded by the Chalmers Energy Area of Advance. Professor Andrea J. Nightingale, Department of Urban and Rural Development, Swedish University of Agricultural Sciences. Email: andrea.nightingale "at" slu.se. During the writing of this article she was also a Professor II at Noragric, the Norwegian University of Life Sciences. The research was funded by the Swedish International Development Agency SIDA; the Swedish Research Council SAREC; a British Academy International Mobility and Partnership Award, and the Swedish Research Council (Vetenskapsrådet) (grant 201503323). Economic support for the fieldwork was also received from Adlerbert Research Foundation and the Nordic Africa Institute. The empirical study was made possible thank to the people in the villages of Mawengi, Madunda, Lupande, Kiwe, Mapogoro, Milo, Mavala, Mdete and Madindu, who opened their homes to the authors and shared their thoughts in interviews. The NGO ACRA welcomed the researchers to study their project in Mawengi and the staff generously shared their time and thoughts as well as facilitated data collection in every way possible. We would like to thank an anonymous reviewer for constructive comments. This is the second article in Hanne Svarstad, Tor A. Benjaminsen and Ragnhild Overå (eds.). 2018. "Power in political ecology", Special Section of the Journal of Political Ecology 25: 350-425.
} 
et les approches sociotechniques dans les études scientifiques et technologiques. Nous examinons comment le pouvoir a été conceptualisé dans le domaine de la «political ecology» et identifions trois tendances qui ont façonné les discussions en cours. Nous développons ensuite notre discussion conceptuelle et demandons explicitement où le pouvoir émerge dans les processus de projets de gouvernance des ressources. Nous identifions quatre endroits que nous illustrons de manière empirique à travers un exemple d'électrification rurale en Tanzanie visant à catalyser le développement social et économique, en fournissant des services d'électricité basés sur l'énergie renouvelable. Notre analyse appuie l'argument selon lequel le pouvoir est relationnel et productif et s'appuie sur des études scientifiques et technologiques pour mettre en évidence le rôle essentiel des éléments non humains dans la co-constitution de la société - la technologie - la nature. Cela nous amène à voir l'exercice du pouvoir comme ayant des effets contradictoires et ambigus. Nous concluons qu'en explorant la tension entre l'agent humain et le pouvoir constitutif, nous maintenons la politique en vie tout au long de l'analyse et montrons pourquoi les choix et les actions intentionnels comptent vraiment dans la manière dont les projets de gouvernance des ressources se déroulent dans la vie quotidienne.

Mots-clés: Puissance; «political ecology»; systèmes sociotechniques; énergie renouvelable; Tanzanie

\section{Resumen}

El poder y lo político han sido temas centrales desde los inicios de la ecología política. En este campo hay conceptualizaciones del poder que suelen ser distintas y en ocasiones opuestas, que muestran el poder tanto como un recurso, un atributo personal, o una relación. El objetivo de este artículo es contribuir a las teorizaciones sobre el poder indagando en perspectivas opositoras con respecto a su papel en el cambio social, presentando además, una conceptualización específica de poder que se basa en aproximaciones tanto sociotécnicas como de ecología política en estudios de ciencia y tecnología. Consideramos cómo el poder ha sido conceptualizado en el campo de la ecología política, e identificamos tres corrientes que han moldeado la discusión actual. Luego desarrollamos nuestra discusión conceptual y explícitamente nos preguntamos de dónde emerge el poder en procesos de proyectos de gobernanza de recursos. Identificamos cuatro locaciones que ilustramos empíricamente a través de un ejemplo de electrificación rural en Tanzania, el cual proyectaba catalizar el desarrollo social y económico al proveer servicio de electricidad basada en energías renovables. Nuestro análisis respalda el argumento que sostiene que el poder es relacional y productivo, y lo basamos en estudios de ciencia y tecnología para presentar el crítico papel de los elementos no humanos en una coconstitución de sociedad-tecnología-naturaleza. Esto nos lleva a ver el ejercicio del poder como algo que tiene efectos contradictorios y ambiguos. Concluimos que, explorando tensiones entre la agencia humana y el poder constitutivo, mantenemos lo político vigente a lo largo del análisis y podemos mostrar por qué las decisiones intencionales y las acciones, realmente importan en cómo los proyectos de gobernanza de recursos se manifiestan en el día a día.

Palabras clave: poder, ecología política, sistemas socio-técnicos, energía renovable, Tanzania

\section{Introduction}

Asking 'where is the power in political ecology?', it seems that power is everywhere and nowhere in this diverse and diffuse field (Svarstad et al. 2018). Ten years ago, Paulson and Gezon wrote that political ecology (PE) was characterized by an "[a]wareness of the deep and complex ways in which dynamics of unequal social and political power affect ecological systems" (2005: 11) and yet a few pages later they also argued that a "more explicit conceptualization of power and politics is needed" (ibid: 28). In this article, we review how power has been conceptualized in PE in order to better tease out why it is that power seems so elusive. Often, power is considered as something that is held by individuals or institutions - for example a formal position or mandate - and exercised for dominance over subordinated individuals. As we illustrate in relation to a rural electrification project in Tanzania, we find such a static and binary understanding of power to be limiting analytically. Rather, when power is understood as a relational, productive force that generates contradictory effects within the same actions, we are able to show how resource governance processes can empower and create new relations of domination at the same time. This shifts our analytical focus to everyday sociotechnical networks through which power is exercised and, through which power quite literally moves. These movements of power in space 
produce tangible material and institutional forms, which themselves then enable and constrain actors in a continual process of emergence, all of which is infused with power.

Our aim is to contribute to theorizations of power by probing where power occurs, using a renewable energy electrification scheme in Tanzania as an empirical example. Electricity presents some unique and particularly potent challenges and opportunities for understanding power. Not only is electricity itself 'power', electrification throws into relief the social and material relations that are required to keep power flowing in many natural resource and energy contexts. Electrification highlights an important generic point about how power is produced in specific situations: it needs to be exercised to be realized, sometimes with quite unintended effects. Our empirical analysis allows us to chart the different moments and transformations of power, helping to make the where and what of power more tangible and at the same time, to illuminate some of the current tensions with how power is conceptualized within PE debates today.

We advocate for a fundamentally relational and emergent understanding of power that sees it as situated and produced - in innumerable interactions among humans and between humans and the non-human world. We draw from feminist theory and related work by Foucault and others to situate the multiple workings of power within everyday contexts (Allen 2002; Dean 2013; Hinchliffe et al. 2013; Jessop 2007; RichardsonNgwenya 2012; Spencer 2012; Swyngedouw 2004). Importantly, our relational conception of power retains an analytical distinction between human agency as power and power that manifests through network dynamics known as 'constitutive power' in the Foucauldian tradition, or, to invoke neo-Marxist traditions, 'structures.' These distinctions matter because, as Amy Allen argues, the relationship between human agency and constitutive power remains under-theorized (Allen 2014). The PE literature illustrates well the gap between those who focus on power as originating in human agency and those who insist on the 'constitutive' pressures of political economies, discourses and institutions as shaping human - environment relations. By holding that gap in view, we are able to work productively with some of the profoundly different material, social and political locations of the (re)production of power relations. In other words, we go some way towards showing where de/stabilization occurs and as such, are able to better understand why the workings of power are situated, contradictory and hard to control.

We begin with a review of the PE literature (section 2) to deconstruct how power has been conceptualized, and then outline our own conceptualization of power in section 3. In section 4, we draw from some of the sociotechnical literature to help capture the importance of considering how non-human, material dimensions of resource governance processes are co-productive of power. In other words, we can find power embodied within dynamic material infrastructures that continuously influence human behavior. In section 5 , we introduce the empirical case that we build on to ground our theoretical analysis, and account for the methodological approach used to study the co-constitution of power relations and an electric power system in communities in the Southern Highlands of Tanzania. We let the case speak to theory and identify methodological entry points for locating power in processes of resource governance. We zoom in on these locations to explain what, how, when and where relational power is produced in the encounter between a development electrification project and local society. The concluding section (6) summarizes the insights in relation to PE literature and the theoretical development of the field.

\section{Conceptualizations of power and environmental change in Political Ecology}

'Power' is a core theme in multiple PE anthologies (Castree and Braun 2001; Paulson and Gezon 2005; Peet and Watts 2004; Rocheleau et al. 1996), yet what power is, where it is located and how to recognize it, is conceptualized quite differently across the field. Some portray power alternatively as "a social relation built on an asymmetrical distribution of resources and risk" (Hornborg 2001: 1), as a "personal attribute", as the "ability of an individual to impose his or her will" or as the "power to shape environments for human action and interaction" (quotes from Paulson et al. 2005: 28). There are also PE scholars inspired by Michel Foucault and Judith Butler who perceive power as a constitutive dimension of social life that produces subjectivities, resources and places and "shapes and pervades all human interactions" (Paulson et al. 2005: 29). There are, we argue, significant theoretical differences between these definitions of power. At a closer look, divergent meanings are often found within the same work, and "power" is conceived of at once as an "entity" that does something ("circulates"), a resource that can be unequally "distributed" or "held", and as a social relation (Gezon 
and Paulson 2005; Slocum et al. 1995). These different understandings of power reflect a wider debate regarding how power should be defined and researched (Allen 2014; Dean 2013). We find that existing conceptualizations have different strengths and weaknesses, and their analytical usefulness depend on the phenomena for study.

In order to navigate in the PE literature and disentangle its diverse uses of power concepts, we turn to philosophical writings on power. Following Allen (2014), we distinguish between three main conceptions of power. First, definitions of power that directly relate (and reserve) power to the realm of human action, to what Allen names as the "action-theoretical" conception of power. In this conception we find scholars who answer the question of what power is by perceiving it either as a 'resource' that is unequally distributed among humans, as a personal 'attribute', or as a relational 'ability' or 'capacity' to act or refrain from action. In these definitions, power is either relational or more thing-like, and more or less static. All are focused on the exercise of human power, that is how power is exercised for, most commonly, domination, or, sometimes, as resistance and empowerment. In this line of work, scholars also engage with how actors exercise power within the constraints of the world around them. Neo-Marxist scholars call those constraints 'structure' (Bryant 1998; Peet and Watts 2004; Ribot and Peluso 2003; Robbins 2011).

Second, Allen identifies the "constitutive" conception of power which builds on the work by Foucault on how power works through discourses and disciplining institutions (e.g. Foucault 1980, 1995). Rather than seeing human agency as the only source of power, the constitutive conception of power "focuses on the fundamentally trans-individual and relational ways" in which individuals and society come to be "constituted by power relations" (Allen 2014: para. 5). In this framing, power is more elusive and has been described as a web, as "capillary power", and a "multiplicity of force relations" (Foucault 1978: 92). Allen identifies also a third, "systemic" conception of power, which refers to historical and very aggregated societal phenomena such as historical origins of rule in specific societies. Some neo-Marxist and Foucauldian scholars can be seen to think through this conception of power in their attention to history (Peet and Watts 2004). The systemic view is, according to Saar (2010), methodologically based in the action-theoretical understanding of individuals exercising power.

As we exemplified above, there is a tendency in PE literature ${ }^{2}$ to move between contradictory actiontheoretical framings (power as a resource vs. power as relational capacity to act) without discussion of the conceptual differences in meaning. We make three observations here: First, we see a logical problem with combining a framing of power as 'resource' with 'constitutive power', which understands power as decentered from individuals. In contrast, power as a relational, situated and contingent capacity to act, we argue, can be combined fruitfully with the constitutive power conception, as these are conceptually consistent in their understanding of power as relational, productive and contingent. According to Allen (2014), Foucault's work contains both action-theoretical and constitutive (relational) framings of power, further supporting our analytical move. Second, we see a problem with combining a micro-level understanding of power as relational, contingent and based in human agency, with a notion of macro-level power as 'structures' if these are treated as stable and objective entities. The potential conflict has to do with how the idea of structures tends to shift the focus from process to state, and from repeated stabilization and temporary closure which is not necessarily successful, to structural determination. ${ }^{3}$ This leads to a third observation: the PE field still contains some unresolved tensions - and antagonism - between neo-Marxist framings of structure and emergent constitutive pressures, tensions which we believe hinder theoretical advances rather than provide for fruitful exchanges. We postulate the problem lies in degrees of perceived stability and elusiveness. Foucault's suggestion that power constitutes the subject has been heavily criticized for leaving no room for free agents (Allen 2014; Lukes 2005). However, Foucault's writings contain multiple framings of constitutive power; it provoked highly fruitful debates; was reinterpreted, and opened up new areas of research. The result is a body of theoretical and empirical

\footnotetext{
2 This is the case not only in political ecology, but it is a generic tendency in literature on power.

${ }^{3}$ According to Lukes (2005: 54-59, 68-69) the tension between human power (agency) and structural determination is recurrent in Marxist thought. He suggests that social life is an interplay between human agency and structure and that agents are responsible for their power exercise because, within the wider structural constraints, they have a degree of autonomy and freedom, that is, they could have acted otherwise. Therefore, the future is not fully closed, and not fully open.
} 
work that enriches the philosophical debate on power that we find highly relevant for PE scholars to engage with, regardless of whether they prioritize Marxist analyses of capitalism and value.

So where is the PE field currently heading? Based on our reading of the PE literature, we see three main trends emerging: first, the relational view of power is gaining ground among PE scholars, increasingly replacing the view of power as a personal attribute or resource. Second, some PE scholars have built on feminist theory and Foucault's work to explore subjection and how social relations and natural environments are mutually constitutive (related to the operation of power and its effects). Third, PE scholars have worked with concepts related to power, such as 'authority' and 'governmentality.' We will briefly comment on these three trends in order to situate our own conceptualization in relation to the field.

\section{Trends in Political Ecology: relations, co-constitution, authority and governmentality}

The first trend in PE is that the field seems to be taking a relational turn. Feminist theory has contributed significantly to advancing a relational understanding of power and unsettling the idea that power is a resource that can be held by individuals. Feminist theorists studied the workings of dominance in order to understand why male privilege persists and to identify strategies to counter-act patriarchy. The conclusion from this work was that power is not simply a question of dominance. The focus shifted from studying women's' situations to studying relations between women and men, and the ways in which gender intersects with other categories of social difference, such as class, sexuality, physical condition, age, caste, and so forth (Allen 2008; Gururani 2002; Shields 2008). Also, the political project of counteracting gender inequality led to theoretical interest in the nurturing and supportive aspects of power, that is, power as capacity to empower or transform oneself or others (Allen 2002; Held 1993).

Empowerment is central to work by feminist political ecology scholars (Agarwal 1992; Rocheleau et al. 1996) who have defined empowerment as "a process through which individuals, as well as local groups and communities, identify and shape their lives and the kind of society in which they live" (Slocum et al. 1995: 4). These scholars have thus defined power as a relation that can be both repressive and productive. However, there has been a tendency to place dominance and empowerment in opposition, whereas other scholars have persuasively argued they are rather in constant tension and closely intertwined (Butler 1990; Dean 2010, 2013; Foucault 1995).

The second trend is that PE scholars have incorporated the idea of constitutive power - as pressures emerging out of multiplicities of interactions. This shows in the integration of concepts such as 'force fields', 'bundles' and 'webs' of power to emphasize broader and more elusive mechanisms and processes whereby power relations are (re)produced, beyond the exercise of power by individuals (Nuijten 2003; Ribot and Peluso 2003; Rocheleau 2008; Sikor et al. 2013). Also, the work on human - environment interactions as mutually constitutive challenges the notion that only humans have power. Notably, some PE scholars have pulled on concepts of "socionature", that is, understanding the world to be inherently social and natural at the same time (Castree and Braun 2001). The socionature concept emphasized the continuous and mutual production of people and their natural environments, which makes an analytical distinction between human society and nature problematic (Hinchliffe et al. 2013). Most importantly for our argument, the locus of power is decentered into relational dynamics rather than individuals or objects in a socionature framing.

As a next step, feminist PE scholars drew on Foucault's ideas around disciplinary power and Butler's work on 'performativity' (Butler 1990) to explore how subjectivities and natural environments become coconstituted (Gururani 2002; Harris 2006; Nightingale 2006, 2011; Sundberg 2004). The work on subjectivities and co-constitution of society-nature represents an important theoretical development in PE in terms of how power relations are conceptualized within resource governance and in ecological change. Subjection signifies the processes whereby individuals internalize and re-express subordinating norms, such as ideas around gender roles. Subjection is ambivalent and attempts to resist culturally prescribed behaviour are contradictory, because they paradoxically also confirm subordinating norms (Allen 1998; Butler 1990; Mahoney and Yngvesson 1992). The integration of these ideas in PE literature has been very important as it led to a body of theoretical and empirical work that managed to capture the 'paradox of resistance' (Butler 1997), that is, that acts of resistance to subjection based on gender, class, caste and other forms of social difference simultaneously confirm and reiterate social hierarchies and discriminatory norms (Harris 2006; Nightingale 2005, 2006). This 
paradox is found in human-environment interactions - and PE scholars show that it has symbolic, material and ecological consequences (Peluso 2009) and it explains the mechanisms whereby the exercise of power is ambiguous and produces contradictory outcomes in many instances.

The third trend we identify is the body of work produced over the last decade on the topics of 'authority' and 'governmentality' (Li 2007; Lund 2006, 2011; Peluso 2009; Vanderkerhove 2011). The literature on authority examines the dynamics created by "people's attempts to secure rights to natural resources by having their access claims recognized as legitimate property by a politico-legal institution" (Sikor and Lund 2009: 1). It links questions of access and property to power and authority, showing how institutional actors assert and reproduce their authority through the process of - more or less successfully - legitimized decisions about resource access and ownership (Fairhead et al. 2012; Ribot 2009; Roth 2009; West et al. 2006). In one of the key articles that has set the tone for theorizing on authority within political ecology, Sikor and Lund describe authority as characterizing the capacity of politico-legal institutional actors to influence other social actors, and as referring to "an instance of power that is associated with at least a minimum of voluntary compliance" (Sikor and Lund 2009: 8).

What we take from the literature on authority is the way it clarifies that formal positions and mandates do not mean that actors hold power (Lund 2008; Ribot 2009). Rather, authority must be exercised over and over through social relations, institutions and material domains, such as granting access and property to claimants (Lund 2008). In this understanding, societal institutions are unstable and work as potential arenas that actors may make use of, rather than stable structures in which power resides permanently. Another crucial insight here is that those who seek to exercise power as authority are not necessarily successful. The exercise of power can act to legitimize their authority or to offer openings to dominated groups to assert their claims in new ways.

Governmentality, taken from a short essay by Foucault (1991), has become an important concept in the PE field. The concept aims to capture the relationship between governing and ways of thinking, or, in other words, different "rationalities" of government (Dean 2010: 24-30). Governmentality is defined as a historically situated and specific "form of power." That is, the "art of government" as it "emerges in Western European societies in the 'early modern period' when the art of government of the state becomes a distinct activity, and when the forms of knowledge and techniques of the human and social sciences become integral to it" (Dean 2010: 28). According to Fletcher (2010: 173), governmentality also has more generic meaning, "designating various particular modes of what [Foucault] calls 'conducting conduct'." In this understanding, the art of government has evolved into multiple forms of 'governmentality' that can be distinguished as particular modes of power (which variously involves governing oneself and/or governing others), helping to show that these forms of power can be exercised to various ends and not only by the state (Lloro-Bidart 2015; McGregor 2015).

A common understanding of governmentality is that it is characterized by taking the population as its object ( $\mathrm{Li}$ 2005), with the aim of improving individuals in the population as "resources to be fostered, to be used and to be optimized" (Dean 2010: 29). This can be achieved through different logics of governmentality, which can co-exist, merge or conflict (see e.g. Lloro-Bidart 2015; Youdelis 2013). Discipline ${ }^{4}$, a form of government working in relation to the population and individuals, by compelling individuals to internalize the social values and norms by means of which they will self-regulate, can be contrasted with neoliberal governmentality (its main goal being economic growth), which constitutes "an environmental type of intervention." It seeks to create "external incentive structures within which individuals, understood as selfinterested rational actors, can be motivated to exhibit appropriate behaviours through manipulation of incentives" (Fletcher 2010: 173-174). ${ }^{5}$ While Foucault initially signaled these forms of government as distinct (Foucault 1991), these notions of 'multiple governmentalities' have been taken up in the PE literature to understand power as constitutive and as action-theoretical.

\footnotetext{
${ }^{4}$ According to Fletcher (2010: 173), Foucault's initial formulation of governmentality stood opposed to discipline, but subsequently Foucault came to view discipline as one form of governmentality among others.

${ }^{5}$ Fletcher (2010) identifies four kinds of governmentality that he finds to be relevant for PE scholars in relation to debates on biodiversity conservation: discipline, neoliberalism, sovereignty (governance through top-down creation and enforcement of regulations), and 'truth' (governance in accordance with particular conception of the nature and order of the universe). For an example of 'truth', see Boelens (2014).
} 
The concept of governmentality has been applied at multiple scales of analysis, both to extremely aggregated phenomena such as "liberal art of government" (Dean 2010; Lukes 2005), and to the effects of larger formations, such as the "development apparatus" or welfare programs (e.g. in development studies where Ferguson has described governmentality as the "decentered" or "subjectless" power of the development apparatus (Ferguson 1994: 19)). It has also been used to describe particular exercises of dominance (at the micro-level) by means of specific techniques, interventions and discourses by the state and other actors (LloroBidart 2015). In the PE literature, two related concepts have emerged and are in focus for current research: 'green governmentality' and 'environmentality' (Agrawal 2005; Fletcher 2010; Lloro-Bidart 2015; McGregor 2015). In short, these concepts are used to analyze the practices governing socioecological relationships (McGregor 2015), how the state and markets - through combinations of discipline and neoliberalism - establish and enforce the 'proper' kind of (sustainable) relationship that humans should have with the environment, as well as the formation of environmental subjects (for more nuance, see Lloro-Bidart 2015).

Hence, the literatures on authority and governmentality develop our understanding of how power works through multiple, but specific, human actions, rationalities, techniques and discourses, and with what effects on social-ecological relations and spaces. We notice that neoliberal governmentality, which intervenes and acts upon the 'environment' - regulatory, organizationally and discursively - may also reshape physical spaces and infrastructure (e.g. by commodifying public space). From a constitutive power perspective, this not only makes power more elusive but also gives neoliberalism a more durable, tangible form in many societies and results in various pressures.

Seen through the lens of Allen's (2014) three conceptions, and the tensions between action-theoretical and constitutive power that she highlights (the systemic conception aligns with the action-theoretical in her view), the empirical studies clearly show that there is an interplay between human agency and constitutive power that enables and constrains actors in their attempts to exercise power. This provides a strong argument for not choosing one of the two conceptions, but rather, staying clear that power is relational, emergent and contingent in both of them, and then, actively working with the tension between them without conflating them. And like Li suggests, power is produced in encounters between spaces, actors, discourses, institutions, knowledges and practices, across multiple levels; it is always dynamic and thus never held (Li 1999).

To summarize our take on the PE literature, there is indeed deep awareness regarding the importance of power in processes of resource governance, but there is a recurring tension between power as a resource that can be possessed and directed on the one hand, versus power as potentiality, a situated capacity which needs to be exercised in order to have any effect, with its outcomes uncertain and ambiguous, on the other hand. There is also a tension between the conceptualization of aggregated phenomena and more elusive pressures as either relatively stable and historically established structures, or as more contingent and unstable force fields. In the following, we will position ourselves in relation to this debate and draw on other literatures to address what we perceive as crucial gaps in PE writings on power.

\section{An embodied and situated conception of power}

Our conception acknowledges both power emerging from human agency and power as 'pressures' that arise out of a multiplicity of interactions between human and non-human elements. Both of these are relational, emergent and productive, but the second kind of power can be distinguished by its more elusive character: in that it takes the shape of discursive, institutional, material or social pressures often without any clear human sender. These pressures emerge at a different time scale than exercises of power embedded in specific actions of individuals and are characterized by being beyond individual control. These analytical distinctions should not be overly interpreted, however. Human agency and constitutive power are always in interplay and tension in complex and dynamic webs and networks consisting of humans and non-humans. The relations are found across multiple levels and scales and are embedded within each other, making the boundaries between them often unclear spatially, temporally and analytically.

We thus theorize the relationship between human agency and constitutive power in the following way: Actors are not 'in power' and they do not 'hold power.' Rather, human power is produced through the continuous and ambiguous (Butler 1990) exercise of power, such that power is only evident in relational, performative moments. We understand human agency to arise from multiple, dynamic and situated moments wherein power 
is exercised, internalized, resisted and transformed in relation to other humans, artifacts and the natural world. Human power therefore can only be understood as situated and embodied practices; workings of power are always 'placed.' The important analytical questions are where and how power is exercised and with what effects, rather than whether people 'have' power or not.

In this view, what are commonly thought of as dominance and empowerment represent a spectrum of the ways in which, and with what intention, actors exercise power in specific situations. Because the exercise of power is always situated, embodied and ambiguous, effects emerging out of our encounters are often not the expected or desired ones. Nevertheless, we can recognize acts that clearly aim at dominance and situations in which dominance is successful. Such situations can involve a more direct (coercive, violent) or indirect (e.g. controlling the agenda) exercises of power. Dominance can also be secured by uneasy, but successful, compromise between actors ( $\mathrm{Li}$ 1999). What is often overlooked, however, is how such 'successful' assertions of power are embedded within wider networks of constitutive power that contribute to their success.

Incorporating a constitutive understanding of ('structural') power to our situated, embodied and relational understanding of human agency helps to explain the where, what and how of power (see also Nightingale and Ojha 2013). When we acknowledge that power emerges from multi-scalar relational networks that transcend and circumscribe individual exercises of power, we are able to show why attempts at exercising power have such ambiguous outcomes. Actors are enabled and constrained by their relative position and alignment within and contestation of dominant discourses, institutions and resource entitlements. This embedding of human agency in constitutive power echoes back to Marx's insistence that "Men [sic] make their own history, but they do not make it as they please; they do not make it under self-selected circumstances, but under circumstances existing already, given and transmitted from the past" (Marx 1852: Ch. 1). We depart from Marxist conceptions by insisting that all exercises of power are contextual in both time and space, leaving open substantially more room to understand both how 'structure' is subtly transformed or (re)produced, even when nothing seemingly changes; and where the possibilities for transformative change might lie (Gibson-Graham 2002; Butler 2009).

When actors, through their material and symbolic practices, reiterate the same pattern over and over, social relations develop and become stabilized (Butler 1990; Foucault 1995). This means that it is not in individual exercises, but through the multiplicity of interactions - on-going exercises of power forming a pattern - that stabilization happens. As shown in the PE literature, constitutive power in this sense originates in discourses ${ }^{6}$ and institutional arrangements (e.g. legal institutions and administrative procedures), which produce and stabilize hierarchies.

In our experience, Butler's suggestion that we can only "trouble" existing relations of dominance and subordination is crucial in understanding the importance of constitutive power in reproducing the discursive realm and subjectivities; why they are so 'sticky' (Probyn 2003). But a closer accounting of where power occurs in everyday life draws our attention to how the localized entrance of new actors or the introduction of new technologies, together with a redistribution of the means by which power is exercised (such as material assets and legal rights), can significantly unsettle dominant patterns, create shifts in the spaces where power is exercised and open up new and radical spaces. Empirically we can observe that significant and radical societal and environmental changes do occur from time to time at various temporal and spatial scales. For example, the current change of human impact on natural environments by orders of magnitude which is rescaling environmental governance and drawing new actors into new relations with each other and their environments.

\section{Technology and social change}

To bring this discussion of power back to our core interests in environment-society dynamics, we find in the field of PE many scholars who study ongoing processes of social-ecological change, from the global scale to very local processes and individual subjectivities. However, there is a tendency to overlook the critical role

\footnotetext{
${ }^{6}$ There are multiple meanings of the concept 'discourse.' In this context discourse refers to sets of interlinked expressions, statements and concepts, such as the 'development discourse.' There are multiple and competing discourses. There is a significant overlap between the concepts of 'discourse' and 'institution.' Partly, it is a matter of disciplinary preference. Power produces both, and discourses is seen as taking the shape of institutions, regulating human behaviour and being more or less codified (Li 2005).
} 
of technology in human-nature interactions, a role which can be crucial in (trans)forming power. We argue that, in general, technology is invisible in PE analyses. The field has so far largely (with some important exceptions, e.g. Bakker and Bridge 2006; Boelens 2014; Bridge 2008) failed to account for the role of technology in struggles over resources. When it is discussed, it is often laden with moral values. Technology in the hands of privileged actors is associated with capitalism and colonialism, laden with negative value (Hornborg 2001). Technology in the hands of subordinated people, in contrast, symbolizes tools of empowerment (Schön et al. 1999). Most importantly, technologies are generally treated as passive tools and are rarely seen as dynamic, coconstitutive and emergent phenomena. To us, technologies are productive in ambiguous and often messy ways. We find it necessary to develop a deeper understanding of technology and its relation to human power in order to conceptualize the production of power in encounters between society-nature-technology - offering us generic insights into understanding emergent socionatures. To this aim, we draw on science and technology studies (STS) and examine, like others before us (Goldman et al. 2011; Monstadt 2009), the common theoretical ground across the fields.

\section{Finding a space for technology in political ecology}

In order to better grasp how the fields of PE and STS share a strong interest in environmental and societal change, but approach such processes from different positions and with attention paid to either the 'socioecological' or the 'sociotechnical', we need to unpack how STS handles power. Both fields are quite wideranging, but there are scholars in both who understand power as relational, productive and emergent, and there are scholars who engage with both and work to integrate them (ibid.).

Sociotechnical studies have been criticized for failing to treat power with any analytical depth (Laurier and Philo 1999). Yet, there are some important insights that emerge from this literature. STS understands technologies to always embody compromise and emerge out of conflict, difference or resistance. Technology and power are both framed as relational and emergent. From the start, the strategies and responses of actors to these "conflict-laden processes" have been in focus (Bijker and Law 1992). In response to criticism, the attention paid to politics has increased over the years (Bijker and Pinch 2012), but explicit theorizations and clear definitions of power are rare in STS literature, with some important exceptions (e.g. Bijker 1995). ${ }^{7}$ Its meaning is somehow taken for granted, which in our view indicates an emphasis on dominance rather than empowerment.

Yet, the sociotechnical literature has developed the idea of constitutive power in significant ways by highlighting the role that artefacts and complex systems play as sources of emerging pressures. For example, the concept of 'actants' is used for artefacts and animals to render non-human elements active rather than passive (Akrich 1992; Latour 1993; Murdoch 1997). The idea of actants does not necessarily suggest that artefacts exercise power, although there are ANT scholars who state that artefacts have agency (Barad 2003; Law 2002). A less radical understanding, which we prefer, is that artefacts become enrolled in exercises of power and play an active role in regulating human behavior - in ways similar to institutions. Artefacts and system configurations embody the power exercised by the designers, they work as 'scripts', which regulate human behavior by encouraging, allowing and forbidding certain types of uses, with social, material and discursive consequences (Akrich 1992). For example, the material structure of electricity networks provides a durable regulatory arrangement, with consequences for the actors involved in supply and use. Power is thus exercised by means of system configurations - a kind of encoding of the exercise of power in hardware and software.

This means that the exercise of power is translated into material forms in infrastructure. Infrastructure embodies the intention of the designer, together with power encoded in the instructions for use. As infrastructures become established realms of codified expert know-how, they achieve 'closure.' Closure is "the process by which facts or artifacts in a provisional state characterized by controversy are molded into a stable state characterized by consensus" (Misa 1992: 109). The concept has taken on multiple meanings, but, at various levels, it is how facts and artefacts, systems and networks gain their "hardness" and solidity (ibid: 111). This translation/embodiment/encoding is a source of stabilization. We argue it is a mechanism whereby human

\footnotetext{
${ }^{7}$ For example, there is no index entrance on power in Bijker et al. (2012), and whereas power is indexed in Bijker and Law (1992), the concept is left undefined and without theorization.
} 
agency (that of system designers and engineers) is given a more durable form. And these durable material and encoded arrangements constitute the infrastructures, discourses and institutions, which in turn condition spaces for action. This is in our view one of the 'places' where it is of crucial importance to theorize how human agency and constitutive power entwine and transform each other. Methodologically, this provides us with a location where PE and STS interlink: in the way that forms of governing act upon the institutional environment and reshape incentive structures, how that leads to changes in built and natural environments, and how this combines to create durable pressures on people and other living beings.

The material durability of infrastructures can lead one to believe that the exercise of power manifested in artefacts is very stable and successful, but this is often not the case. Local conditions, willful users and interactions with other non-human components in technical systems tend to modify, reinterpret and contest the prescribed 'proper' use intended by designers (Bijker and Law 1992). Also when power is embedded in infrastructure it evokes responses and counteraction. This indicates that mediation is at the core of human-nonhuman interactions. Thus, the 'script' is rewritten as it is played out (Akrich 1992), again and again in the ongoing encounters between humans and things. The sociotechnical understanding of power described here sees power as relational and productive, and does not align well with the idea of power as an entity or attribute that is 'held.'

There is thus theoretical similarity - and in our view, common ground - between the idea of mutually constitutive 'socionatures' in PE and 'sociotechnical systems' that emerge from processes of co-constitution between technologies and social relations. Where scholars of power have examined the sources of stability of the social order, sociotechnical scholars (Misa 1992; Pinch and Bijker 1984) focus on processes of closure or 'lock-in' whereby technologies become stabilized. The process of closure may involve the reproduction or restructuring of power relationships, and it is a contingent achievement (Bijker and Law 1992). Here, it is the technology that becomes stabilized, rather than social hierarchies - these can be reproduced or destabilized in the process. In the case of electrification, we find that social hierarchies are both stabilized and destabilized simultaneously throughout the process whereby the electric power system gains its material and institutional solidity. It is therefore crucial to probe how power is situated, embodied and placed. We now turn to our empirical example of electrification in Tanzania to further elaborate these points.

\section{Where is the power?}

In this section we propose an explicit answer to where power emerges in processes related to resource governance. We suggest four 'locations' that can be used as generic methodological entry points to study how power relations and resource governance projects become co-constituted. We have argued that non-human elements co-produce power, and therefore, we assume that resource characteristics and 'materiality' shape the interplay between humans-non-humans in significant ways, thus giving rise to particular and divergent workings of power within these generic locations. To illustrate what we mean by this, we will briefly discuss how electricity is a unique resource, and then present our generic locations. After that, we go back into the specific and draw on an empirical case study to show the workings of power within these four locations.

\section{Electricity as enabler of symbolic and material change}

Electricity shares many characteristics with other resources, but its relation to power is unique because of its particular characteristics. Electricity is not a vital resource in and of itself, it is an energy carrier, a power potential that resides in the electricity infrastructure. If combined with other technologies, it can transform and enhance human capacity ${ }^{8}$ to communicate, carry out mechanical work, catalyze chemical reactions, etc. These other technologies are also means to an end at the same time as they are desired entities in themselves. For example, the electric machinery in a workshop is a resource that can be used to do work. Acquiring specific machines is an exercise of power, requiring action and mobilization of assets. Once an electric saw, or milling machine is there, it changes the potentiality for action. Its very presence reconfigures social relations: like the electric grid, it symbolizes power and authority, it generates expectations: worry for losing one's job; pride in

\footnotetext{
${ }^{8}$ Bijker and Pinch (2012: xix) highlight how technologies in this sense complicates the relation between agency and structure.
} 
knowing how to use it. But if it is not used, but instead gathers dust in a shed, it can come to symbolize failure, incompetence or loss. For actors to control and use the machine, knowledge and a 'power source' must be mobilized. The designer can effectively condition access by making the machine's (or the electric appliance's) user interface friendly to beginners or alternatively, requiring skilled expertise. Once the machine/computer/mobile phone is 'powered' by electricity and in the hands of an actor with the right knowledge, it can do the work for which it was intended, for a moment enhancing and transforming the capacities of the user, allowing humans to make change in a way they could not before and possibly creating a shift in the user's social position.

Here, we will not expand the discussion beyond these mundane examples of what access to electricity and electric devices can mean for people in rural Tanzania, however, the point is that electricity embodies the important conceptual point that power needs to be exercised to make a difference. Other resources and infrastructures have different characteristics that shape the encounter and process of co-constitution between resource governance projects and relations of power in specific ways. Still, there are, we suggest, similarities in the power interplay that emerges - which can be conceptualized as four generic 'locations'.

\section{Locations of power in resource governance projects}

We see four locations where de/stabilization takes place. As we zoom in to provide some empirical examples of the production of power at these locations, we will actively work with the analytical distinction, and tension, between human agency and constitutive power. This allows us to show how they interplay at the different locations to produce specific effects. Further, by keeping them apart, we can keep the politics in the process alive, showing the importance of intentional human actions and decisions, and how these matter as they shape the process in important ways, enable and constrain the space for people to respond to the project, and give direction to the process that unfolds on the ground. However, it is by keeping in sight the non-human elements and material dimensions that we get to the core of why the idea of constitutive power is so fruitful analytically - it helps decenter power from the individual or object to relational dynamics, and thereby capture how the co-constitution process is one of mediation between intentional action and resource/technology characteristics. Both are constantly reshaped in the multiplicity of human-non-human interactions - and therefore the process can only be partially steered and not controlled. This takes us away from deterministic accounts and reintroduces politics into the center of resource governance - the latter being a key criticism of actor-network conceptions of sociotechnical systems (Laurier and Philo 1999).

So, to answer the question of where is the power we use our conceptualization to further characterize the following four locations in resource governance processes, most of which are fairly familiar within PE framings but which do not have a consistent treatment of power within the literature:

(a) knowledges and ontologies shaping resource governance processes;

(b) the contingent manifestation of power interplay in dynamic systems configurations;

(c) access and entitlements;

(d) the everyday lives of people.

The first location - knowledges and ontologies - is a critical part of how dominant actors shape resource governance projects based on different knowledges and according to certain "logics" around what is true and desired: world views and assumptions underlying the project interventions regarding what is the problem/situation, what ought to be protected/sustained/changed/achieved and how this is to be done (Goldman et al. 2011; Rangan and Kull 2008; Zimmerer 2000). Knowledges are temporary stabilizations and internalizations of ontologies, which are wider logics of what the world is and how it works. These knowledges and ontologies are critical in that they underlie how dominant actors shape the early stages of project planning, design, and implementation by setting goals and objectives, selecting strategies and framings in their communication with and justification of the project in relation to other actors. As Li (1999) has highlighted, that process is full of negotiation, compromise and adjustments, often taking the shape of "assemblages" rather than neatly designed and steered projects. Human agency is very important indeed in shaping projects, but to a 
large degree, the actors involved act in response to constitutive pressures such as constraining institutionalized rules and practices, expectations and assumptions based in dominant discourses, expert knowledges and sectorial "business as usual" (see Goldman et al. 2011). These sectorial 'expert-based' knowledges and practices push strongly towards 'closure'.

The second location is the contingent manifestation of these assemblages in dynamic system configurations. These configurations include the key elements of the project - the actors and their networks; the (natural and material) resources; technologies (hardware and software); activities and practices that constitute core means by which goals are to be achieved; and the institutions mobilized and established to govern the use of resources. Configurations change as elements are repositioned and reorganized in relation to each other and the context. Configurations are the embodied (in infrastructures) and encoded (in institutions) result of processes of translation, negotiation and compromise, as well as manifestations of ongoing contestations, for example in terms of how actors demand a change of rules, upgrading of or access to infrastructures. In many sectors there are 'blueprint' designs working as pressures for closure, but these are constantly challenged by actors arguing for the need to adapt project blueprints to contextual conditions and demands.

The third location is access and entitlements: that is, the processes whereby actors try to access, control and derive benefits from the available resource system. This has been a key focus in PE for a long time and the literature provides a rich understanding of empirical as well as theoretical aspects of access dynamics and resource entitlements (e.g. Peet and Watts 2004; Ribot and Peluso 2003; Rocheleau et al. 1996). The process of gaining access to resources illustrates in much detail the interplay between human agency and constitutive power. People are constrained and enabled by their position in social hierarchies and the existing resource distribution; dominant discourses and institutions influence their space for maneuver and combine with individuals' subjectivities and strategic action to overcome access barriers and control access of others.

The fourth location where power emerges is the everyday lives of people. The consequences of how resource access and use become organized manifest at multiple levels, from individual, to family, group, community and in relation to surrounding society. Depending on the resource, the changes may occur in multiple domains of the everyday - in the case of electricity, changes can occur in the organization around work and leisure, in the interrelated values attributed to time-labor-resources, in people's mobility, or in the use and meaning of everyday spaces (Ahlborg in press). The researcher can identify material and symbolic shifts in these domains, and importantly, in the subjectivities associated with them (Nightingale 2006). Resource governance projects often have unintended consequences and messy outcomes that are due to the way intentional action combines in unexpected ways with constitutive pressures that are outside the control of project implementers. Examples from the PE literature include interventions that intended to benefit women economically, which led to initial gains but loss of income and resource access in longer time perspective (Carney 1996; Harris 2006; Schroeder 1997).

We have specified these four locations in order to address the question of where power emerges in resource governance projects. Using the locations as entry points, it is possible to work one's way back and forth in time, and across spaces and organizational levels, from individual to various collectives. Within these locations, we can zoom in on more specific situations, moments and spaces in the encounters between projects and particular contexts - which we will now exemplify based on a case of rural electrification - to further deepen our understanding of how, why and where de/stabilization of power occurs.

\section{Introduction to the Mawengi electrification programme}

The Mawengi village is located in Ludewa district in the Southern Highlands of Tanzania. It has been the center for a process of decentralized rural electrification, in which an international NGO has constructed a hydropower system of $300 \mathrm{~kW}$ capacity and a mini-grid to supply Mawengi and nearby villages with electricity. The NGO ACRA (Cooperazione Rurale in Africa e America Latina) planned and implemented the program in partnership with the local church, funded by international and national donors. Before the program, people in the area relied on diesel generators and batteries for powering electric appliances. ACRA initiated the process in 2005 and the construction of the plant and mini-grid beginning in 2006. Service delivery to the first customers 
started in June 2010, providing reliable electricity supply at relatively low cost and ACRA established a local utility to legally own the system.

In phase II of the program (2011-2014), ACRA and the local utility continued to develop the infrastructure. Also, a more ambitious approach was adopted and a number of activities were undertaken in parallel. Program activities focused on organizational, economic and institutional development of the local utility organization. ACRA worked closely with local utility staff in an explicit attempt to enhance their capacity to independently manage infrastructure and service delivery to customers. This was promoted via: development of a new regulation for the utility; training of staff; introduction of stricter customer regulations (and enforcement of payment for services by sanction of disconnection); expansion of the customer base; stepwise increase of tariffs; and introduction of pre-paid meters. ACRA also developed a strategy to achieve synergies between electrification and other sectors, through activities in education, agriculture and business training. Together, these actions partly reshaped the interplay between system and context and led to a positive loop emerging between the development of infrastructure, growing numbers of customers, satisfied users who increased their use over time, and the economic capacity of the local utility. At the same time, the process involved numerous tensions and contestations among actors involved, and it was far from a smooth or easy ride for the NGO and local utility.

In 2014, the energy system supplied services at high quality to local communities, at a cost similar to that of the national utility company. A couple of months before ACRA ended its involvement in the development program, the grid reached 9 communities and the utility had 1,200 paying customers (i.e. 1,200 connections, whereas the number of users was much higher), with an average load of $80 \mathrm{~kW}$. In comparison to other hydropower systems in the nearby area, the share of economically productive electricity uses was high and there was evidence of growth of the local economy (Ahlborg and Sjöstedt 2015).

\section{Case study methods and analytical strategy}

Ahlborg has studied the case of the Mawengi electrification program since 2012. After an initial oneweek visit in 2012, a qualitative case study was carried out during three months in 2013. Short follow-up visits took place in 2014 and 2015. Data has been collected through semi-structured interviews, observation, group discussions, analysis of project documentation and technical system documentation. Around 140 interviews have been carried out so far, covering different aspects of the process and reflecting the perspectives of the many different actors involved. Coding (using coding software) and analysis of transcribed interviews has been conducted in several stages, with different but overlapping focii for the different publications (details are found in Ahlborg 2015; Ahlborg and Sjöstedt 2015).

\section{The emergence of power in a small-scale electrification program}

The electrification process in Mawengi is an arena for local politics and contestations illustrating well the elusive, contingent and ambiguous nature of power - the process has been steered in certain directions based on intentional action, but also taken unexpected turns. Importantly, not only human actors have driven the process in certain directions. Technology characteristics and place-specific conditions have shaped the encounter between the electric power system and the local context. The case has been explored in more detail in other publications (Ahlborg 2015; Ahlborg and Sjöstedt 2015). Here, we illustrate the interactions and tensions between human agency and constitutive power for each of the four locations and relate these back to our theorization of power.

1. Knowledges and ontologies: The electrification process was shaped in fundamental ways by the implementing NGO and the fact that it was driven as a "development project" with donor funding. This set the financial conditions and time frames for the process. The construction of infrastructure (led by engineers, constructors and technicians) dominated the first years of implementation. Over time, other issues, related to service delivery, economic viability, capacity building, community development and long-term sustainability were given increasing attention. Underlying the project implementation is a set of established NGO practices on how to carry out development projects, and specific ideas - shared by both the NGO, the international development cooperation sector, the Tanzanian government and a majority of local citizens - around what is 
desired: electricity is considered crucial for development, it is a symbol of progress and modernity. The discursive formations around "the importance of electricity" and the "sustainability" of renewable energy sources supported the NGO in its attempts to get funding for the project, partner with local actors and mobilize people to contribute "in-kind" voluntary labor to the project implementation in a manner that illustrates well how constitutive power ensures some actors and spaces are able to exert their visions for progress.

However, the discourse on the importance of electricity for development met, mingled and contrasted with other discourses, such as the Kiswahili concept of Maendeleo - 'development' - that was often referred to by both villagers and NGO staff and which people associate with the former President Julius Nyerere and his insistence that development is the responsibility of citizens (Green 2014). People also expressed a good amount of skepticism in interviews, when telling the story of how they first reacted to the project. As one customer explained: "At that time I did not believe, because we were often being promised things but we did not get them." Many adopted a wait-and-see policy, which frustrated the NGO staff and delayed the construction process. One reason for this was previous negative experiences of other NGO or government-led development projects that had not produced any lasting results. People expressed how they were torn between a strong sense that the project "could not be real" and hope that the "dream" of having electricity could come true; their inertia being a potent form of exercising power in the face of high-status actors coming with promises of development (Li 2007; Scott 1985). In the words of a young woman, she "was looking at the place where the project was expected to be constructed, thinking of the required materials and how they were going to construct the roads and I thought this project is not going to be achieved." Others decided to pay for internal wiring of their houses in anticipation of having electricity, at the same time as they strongly doubted promises made. Thus, at the early stages of the process, actions by the NGO (including its attempts to establish trust) and the reactions and responses by individuals and collectives in the villages were decisive in shaping the process, but motivated and situated in a field of constitutive power where collective imaginations around what was desired (which was rarely contested) encountered much more diverse views regarding what could be done and how things should be done. Here we see quite clearly the interplay of human agency and constitutive pressures.

2. Manifestation into dynamic system configuration: Increasingly, as plans materialized into grid infrastructure and electric lines passing across the village space and, eventually, electric lights in the night, interest in becoming part of the project increased substantially. The electric grid created zones of danger and prohibition in relation to the physical infrastructure as well as a network of lit and unlit places. People living in the hills upstream from the hydropower plant could see the lights below in the valley at night, which a teacher explained made him feel sad that their village didn't have electricity. The spatial outline of the grid conditioned who was eligible for connection, and the decision of where to place the transformers was based on perceptions of where the customer potential was high enough. Delegations of local leaders from nearby, but not connected, villages visited the local office in Mawengi to insist that their village should also be connected. In these negotiations, the NGO staff and local utility staff had to consider numerous technical, geographical and socioeconomic factors: cost for grid expansion; potential customer base and income; current average and peak load; and potential increase of load in already connected villages. These mixed with political and ethical considerations regarding whether to prioritize households, businesses or public services, and whether to concentrate the grid to few villages or expand to multiple village centers. The translation of plans into infrastructure, and encoding of attitudes and priorities into regulations, produced new patterns of inclusion and exclusion within and between villages, with electric lights at night demarcating the division between people. These political effects were produced from the unique interplay between the electric power system, the local geographical setting and social relations.

3. Access and entitlements: Given the way that electricity access and use requires the mobilization of resources and entitlements, local 'elites' are in a better position to make use of new opportunities, whereas poverty constrains the possibilities for people with low incomes to become electricity customers, invest in appliances or afford commercial services. Norms around gender curtail women's space for action: their participation in decision-making, behavior in public space and entrance into new roles and activities. For example, women's participation in meetings was influenced by their expectation regarding whether alcohol would be consumed during the meeting and whether they felt comfortable if that was the case. The pressures felt by individuals are simultaneously discursive, institutionalized and material. As a consequence, the overall 
pattern is that disadvantaged groups struggle to gain access to electricity and related benefits, while people who manage to gain access often experience economic and social benefits. By and large, social inequality and existing hierarchies are being (re)produced in the electrification process in Mawengi. At the same time, electrification produced destabilization due to the way electricity services open up new room for distributed action. In the connected villages, individuals assisted each other in overcoming barriers to access through collective and supportive action, and many services were made available for the wider public to the benefit of a majority of families. For example, electricity connections were (illegally) shared, and services like mobile phone charging emerged in local shops. In one neighborhood, inhabitants assisted each other in digging trenches for cables, thereby cutting labor cost for connecting to the grid.

Importantly, the newness of electricity in this context means that it is a quite undefined 'space' which is not yet reserved for high-status people or men only. Also, the NGO took specific action to prevent so called elite capture of the project by instituting a utility regulation that prohibits local leaders and government employees from gaining positions of leadership within the utility company. Thus, we can see how the processes around access and entitlements become a location where the encounter between project and local context produces simultaneously a stabilization of social inequality and enhanced social mobility, which destabilizes social practices and hierarchies.

4. Everyday lives: There are specific places for control over the electric power system - the powerhouse, the transformers and the office - that work as important sites for social negotiations, illustrating how resource governance projects can influence everyday life. On the one hand, the established mode of operating smallscale electric power systems and grid infrastructure builds on centralized control of service provision by the utility company. On the other hand, access and use of services are distributed in space and generate dispersed activities and decentralized social organization and control. The effects of these tensions between centralization and distributed agency, in both project implementation, system configuration and electricity access, are found at the micro-level in everyday practice, where many people change daily routines: such as the time they go to bed, what places they visit, how they organize their workday and socialize with friends and family. The wide range of applications that electricity makes possible (its unique quality as energy carrier), and the social organization necessary to keep the hydropower system and service delivery working well over time, produce shifts in many domains of everyday life. The multiplicity of interactions and shifts is, we find, of critical importance for understanding why electrification processes are hard to control.

Importantly, electricity can reconfigure daily life in both time and space, which opens up possibilities for deeper shifts in power relations, as specific places are entangled in power exercise and the strategic 'making' of identities (Valentine 2007). To exemplify, the utility office space in Mawengi is a place where new identities emerge and these partly destabilize existing hierarchies. 'Staff' and 'customers' exercise power practically and discursively in innumerable ways, thereby repositioning themselves in relation to each other and to the electric system. For example, the dynamic around paying bills, asking for advice, service or a grace period for paying bills is shaped by and serves to (re)shape intersectional social relations. People who have not previously shared a collective identity (perhaps a male local political leader and a young woman) find themselves waiting in line together, being treated the same or differently by staff. The utility staff control the technical system, handle money, make decisions, provide help, argue, assert authority, obey orders and so-on. And we need to note here, that because of the deliberate attempts by the NGO to force the utility company to employ 'unusual suspects', it was not uncommon for a male, older, political leader to have to negotiate with a younger woman who had the ability to charge fines and refuse to retain access to electricity when bills were delinquent. The office is a place for negotiation of one's "place-in-the-world", as an individual and as collective (see Ferguson 2006).

We argued in Section 3 that the interactions between agency and constitutive power are cross-scale and multi-level. Here, we would like to add that the time scale at which one studies electrification processes determines what one can see. Some changes are slow to emerge, other are immediate. In hindsight, one may be able to evaluate how deep they were - if the material and symbolic shifts are significant enough, they may do more than 'trouble' existing hierarchies and produce more fundamental change and contestation of gender and class relations. Not enough time has passed for us to say if this is the case in Mawengi. But if we zoom out analytically, we find that the visual impact of electricity brings a symbolic repositioning not only for individuals, but also for the community and its relation to surrounding society, where the electrified villages are now 
perceived by their inhabitants to be "connected" and "part of modernity." With a wider analytical focus, we also see how the degree to which electrification becomes a catalyst for economic and social change at the local level is conditioned by the wider political economy and other factors and processes limiting the economic impact electricity services can have on rural communities. In other words, we see human agency in various forms system designs of engineers, infrastructure built by both local and outside 'experts', the paying of bills - quite literally lighting up and reflecting constitutive power - development projects, government directives and sectorial established practice - across landscapes in ways that are far from random and which carry tremendous symbolic impact.

We have provided examples from the electrification process in Mawengi to illustrate how we work with the question of where power emerges in resource governance projects. Within the four 'locations' we identified specific moments and places where human agency and constitutive pressures co-produced shifts in daily life and social hierarchies. An important reason why the process is hard to control has to do with the multiplicity of interactions and shifts in many domains simultaneously, where the introduction of this extremely useful energy carrier temporarily destabilizes social hierarchies by opening up new room for maneuver, also for disadvantaged groups.

\section{Conclusions}

In this article, we aim to contribute to theorizations of power in the PE field by probing where power occurs within resource governance projects in general, and in a case of decentralized electrification in Tanzania in particular. We have suggested a framework wherein we are able to show how it is analytically fruitful to conceptualize power as relational, situated and emergent in ways that produce contradictory and ambiguous effects, which are hard to control. Our framework theorizes power relations, from the micro to macro-level of society, as dynamic and shaped by multiple tensions: between dominance-empowerment; human agencyconstitutive power; and closure-destabilization. By probing these tensions, we have tried to address one of Amy Allen's questions on power and more consistently think through the relationship between human agency and constitutive power. We also did this in order to bridge across the cleavage in political ecology literature between scholars preferring the concept of 'structure' in the Marxist tradition and those who adhere to the Foucauldian set of ideas around 'constitutive power.'

What is perhaps new with our analysis in relation to previous engagements with power in PE is the way we have explicitly asked the question of where is power located, and attempted to provide concrete answers to this question. We conceptualize not only what power is, how it works, but also, where and when it produces de/stabilization of social hierarchies and dominant discourses and practices. In order to answer the question of where power emerges, we propose four generic locations as methodological entry-points to the study of power in resources governance projects. Our conceptualization of power and these four locations are not new or entirely different from earlier framings and concepts used by PE scholars, rather they help signal where the debate has been and why contradictory conceptualizations of power can be problematic. Here, we hope to complement previous work and add a bit of clarity by highlighting inconsistencies and common ground in how power is operationalized within PE studies.

We follow Amy Allen in our characterization of three main conceptions of power, and actively work with two of them - the action-theoretical and constitutive conceptions. By holding these two in tension we keep politics alive throughout our analysis, by insisting that intentional choices and the exercise of power by individual actors really matter for how projects play out, and with what consequences on the everyday lives of people. At the same time, a strong emphasis on human relations at the expense of constitutive power, as decentered from human agency and linked more clearly to discourses, institutions and non-human elements (technologies and nature), does not allow us to capture important political dimensions related to how particular discourse formations, institutions and infrastructures enable and constrain the space for action and co-produce pressures and effects that are more or less beyond human control. We therefore have probed how human agency is simultaneously generative of, produced within and constrained by constitutive power.

To make this concrete, we used empirical examples of how a particular electric power system comes to shape, interplay with and embody the exercise of power in hardware and software. By focusing our attention on the multiplicity of interactions between humans and non-human elements, rather than allocating power to 
people or objects that are powerful, we can explain why power produces ambiguous effects in resource governance projects that seek to change society intentionally in certain directions. We gave an example of this ambiguity emerging in the location we call 'access and entitlements', where the introduction of electricity and relations of power co-produce an expanding room for individual and collective action - with expected and unforeseen opportunities - where privileged individuals are in a better position to mobilize assets and make use of the new system. Simultaneously, electricity as a resource creates shifts in so many domains of everyday life that it enables distributed use and opens up new social spaces that are hard to control. These shifts are produced out of agency, coincidence, luck, entitlements, contestations, desires, spatial locations and human-technology interactions at multiple scales and levels. We know that pressures for closure and stabilization are many and strong, but still, radical social change does occur from time to time. Based on the way we have conceptualized power and analyzed its workings in electrification processes, we propose that the potential for more profound destabilization of intersectional social hierarchies including gender and class will be found in this multiplicity of interactions we have described. It is in the expanding space for distributed agency that these particular processes involve the chance to do more than trouble dominant discourses, and where more profound shifts can occur. This leads us to reflect that our framing of power and methodological choices are very important for how we come to understand such non-linear processes.

\section{References}

Agarwal, B. 1992. The gender and environment debate: lessons from India. Feminist Studies 18(1): 119-158.

Agrawal, A. 2005. Environmentality: technologies of government and the making of subjects. Durham, NC: Duke University Press.

Ahlborg, H. 2015. Walking along the lines of power. A systems approach to understanding co-emergence of society, technology and nature in processes of rural electrification. Ph.D. dissertation. Gothenburg: Chalmers University of Technology.

Ahlborg, H. 2017. Towards a conceptualization of power in energy transitions. Environmental Innovation and Societal Transitions. 25(Supplement C): 122-141.

Ahlborg, H. and M. Sjöstedt 2015. Small-scale hydropower in Africa: Socio-technical designs for renewable energy in Tanzanian villages. Energy Research and Social Science 5: 20-33.

Akrich, M. 1992. The de-scription of technical objects. In Bijker, W.E. and J. Law (eds.) Shaping technology/building society: studies in sociotechnical change. Cambridge, MA: MIT Press. Pp. 205224.

Allen, A. 1998. Power trouble: performativity as critical theory. Constellations 5(4): 456-71.

Allen, A. 2002. Power, subjectivity, and agency: between Arendt and Foucault. International Journal of Philosophical Studies 10(2): 131-149.

Allen, A. 2008. Power and the politics of difference: oppression, empowerment, and transnational justice. Hypatia 23: 156-172.

Allen, A. 2014. Feminist perspectives on power. In Zalta, E.N. (ed.) The Stanford encyclopedia of philosophy Stanford: Stanford University Press.

Barad, K. 2003. Posthumanist performativity: toward an understanding of how matter comes to matter. Signs 28(3): 801-831.

Bijker, W.E. 1995. Of bicycles, bakelites and bulbs: towards a theory of sociotechnical change. Cambridge, MA: MIT Press.

Bijker, W.E., T.P. Hughes and T. Pinch (eds.) 2012. The social construction of technological systems: new directions in the sociology and history of technology. Cambridge, MA: MIT Press.

Bijker, W.E. and J. Law 1992. General introduction. In Bijker, W.E. and J. Law (eds.) Shaping technology/building society: studies in sociotechnical change. Cambridge, MA: MIT Press: 1-16. 
Bijker, W.E. and T. Pinch. 2012. Preface to the anniversary edition. In Bijker, W.E., T.P. Hughes and T. Pinch (eds.) The social construction of technological systems: new directions in the sociology and history of technology. Cambridge, MA: MIT Press. Pp. xi-xxxiv.

Bridge, G. 2008. Global production networks and the extractive sector: governing resource-based development. Journal of Economic Geography 8(3): 389-419.

Bakker, K. and G. Bridge. 2006. Material worlds? Resource geographies and the 'matter of nature'. Progress in Human Geography 30: 5-27.

Boelens, R. 2014. Cultural politics and the hydrosocial cycle: water, power and identity in the Andean highlands. Geoforum 57: 234-247.

Bryant, R.L. 1998. Power, knowledge and political ecology in the Third World: A Review. Progress in Physical Geography 22(1): 79-94.

Butler, J. 1990. Gender trouble: feminism and the subversion of identity. London: Routledge.

Butler, J. 1997. The psychic life of power. Stanford: Stanford University Press.

Butler, J. 2009. Frames of war: when is life grievable? London: Verso.

Carney, J. 1996. Converting the wetlands, engendering the environment. In R. Peet and M.J. Watts (eds.) Liberation ecologies: environment, development, social movements. London: Routledge. Pp. 165-186.

Castree, N. and B. Braun (eds.) 2001. Social nature: theory, practice, and politics. Oxford: Blackwell.

Dean, M. 2010. Governmentality: power and rule in modern society. $2^{\text {nd }}$ ed. Thousand Oaks: Sage.

Dean, M. 2013. The signature of power: sovereignty, governmentality and biopolitics. Thousand Oaks: Sage.

Fairhead, J., M. Leach and I. Scoones. 2012. Green grabbing: a new appropriation of nature? Journal of Peasant Studies 39(2): 237-261.

Ferguson, J. 1994. The anti-politics machine: "development", depoliticization, and bureaucratic power in Lesotho. Minneapolis: University of Minnesota Press.

Ferguson, J. 2006. Global shadows: Africa in the neoliberal world order. Durham, N.C.: Duke University Press.

Fletcher, R. 2010. Neoliberal environmentality: towards a poststructuralist political ecology of the conservation debate. Conservation and Society 8(3): 171-181.

Foucault, M. 1978. The history of sexuality: an introduction. Vol. 1 Translated by R. Hurley. New York: Vintage.

Foucault, M. 1980. Power/knowledge: selected interviews and other writings. 1972-1977. New York: Pantheon Books.

Foucault, M. 1991. Governmentality. In Burchell, G., C. Gordon and P. Miller. The Foucault effect: studies in governmentality. Chicago: University of Chicago Press. Pp. 87-104.

Foucault, M. 1995. Discipline and punishment. New York: Vintage Books.

Gezon, L.L. and S. Paulson. 2005. Place, power, difference: multiscale research at the dawn of the twenty-first century. In Paulson, S. and L.L. Gezon (eds.). Political ecology across spaces, scales and social groups. New Brunswick, NJ: Rutgers University Press. Pp. 1-16.

Gibson-Graham, J.K. 2002. Beyond global vs. local: economic politics outside the binary frame. In Herod, A. and M.W. Wright (eds.) Geographies of power: placing scale. Oxford: Blackwell. Pp. 25-57.

Goldman, M.J., P. Nadasdy and M.D. Turner (eds.). 2011. Knowing nature: conversations at the intersection of political ecology and science studies. Chicago: University of Chicago Press.

Green, M. 2014. The development state: aid, culture and civil society in Tanzania. Oxford: James Currey.

Gururani, S. 2002. Forests of pleasure and pain: gendered practices of labor and livelihood in the forests of the Kumaon Himalayas, India. Gender, Place and Culture: A Journal of Feminist Geography 9: 229-243.

Harris, L.M. 2006. Irrigation, gender, and social geographies of the changing waterscapes of southeastern Anatolia. Environment and Planning D: Society and Space 24: 187-213.

Held, V. 1993. Feminist morality: transforming culture, society, and politics. Chicago: University of Chicago Press. 
Hinchliffe, S., J. Allen, S. Lavau, N. Bingham and S. Carter. 2013. Biosecurity and the topologies of infected life: from borderlines to borderlands. Transactions of the Institute of British Geographers 38(4): 531543.

Hornborg, A. 2001. The power of the machine: global inequalities of economy, technology, and environment. Walnut Creek, California: Altamira.

Jessop, B. 2007. State power: a strategic-relational approach. Cambridge: Polity Press.

Latour, B. 1993. We have never been modern. Cambridge: Harvard University Press.

Laurier, E. and C. Philo 1999. X-morphising: review essay of Bruno Latour's Aramis, or the love of technology. Environment and Planning A 31: 1047-1071.

Law, J. 2002. Aircraft stories: decentering the object in technoscience. Durham, N.C.: Duke University Press.

Li, T.M. 1999. Compromising power: development, culture, and rule in Indonesia. Cultural Anthropology 14(3): 295-322.

Li, T.M. 2005. Beyond "the state" and failed schemes. American Anthropologist 107(3): 383-394.

Li, T.M. 2007. The will to improve: governmentality, development, and the practice of politics. Durham, N.C.: Duke University Press.

Lloro-Bidart, T. 2015. Neoliberal and disciplinary environmentality and 'sustainable seafood' consumption: storying environmentally responsible action. Environmental Education Research: 1-18.

Lukes, S. 2005. Power: a radical view. Basingstoke: Palgrave Macmillan.

Lund, C. 2006. Twilight institutions: public authority and local politics. Development and Change 37(4) 685705.

Lund, C. 2008. Local politics and the dynamics of property in Africa. Cambridge: Cambridge University Press.

Lund, C. 2011. Property and citizenship: conceptually connecting land rights and belonging in Africa. Africa Spectrum 46(3): 71-75.

Mahoney, M.A. and B. Yngvesson. 1992. The construction of subjectivity and the paradox of resistance: reintegrating feminist anthropology and psychology. Signs 18(1): 44-73.

Marx, K. 1852. The eighteenth Brumaire of Louis Napoleon. Available at https://www.marxists.org/archive/marx/works/1852/18th-brumaire/

McGregor, A., E. Challies, P. Howson, R. Astuti, R. Dixon, B. Haalboom, M. Gavin, L. Tacconi and S. Afiff. 2015. Beyond carbon, more than forest? REDD+ governmentality in Indonesia. Environment and Planning A 47(1): 138-155.

Misa, T. 1992. Controversy and closure in technological change: constructing "steel". In W.E. Bijker and J. Law (eds.). Shaping technology/building society: studies in sociotechnical change. Cambridge, MA: MIT Press. Pp. 109-139.

Monstadt, J. 2009. Conceptualizing the political ecology of urban infrastructures: insights from technology and urban studies. Environment and Planning A 41: 1924-1942.

Murdoch, J. 1997. Inhuman/nonhuman/human: actor-network theory and the prospects for a nondualistic and symmetrical perspective on nature and society. Environment and Planning D: Society and Space 15: 731-756.

Nightingale, A.J. 2005 'The experts taught us all we know': professionalisation and knowledge in Nepalese community forestry. Antipode 34(3): 581-604.

Nightingale, A.J. 2006. The nature of gender: work, gender, and environment. Environment and Planning D: Society and Space 24: 165-85.

Nightingale, A.J. 2011. Bounding difference: Intersectionality and the material production of gender, caste, class and environment in Nepal . Geoforum 42(2): 153-162.

Nightingale, A.J. and H.R Ojha. 2013. Rethinking power and authority: symbolic violence and subjectivity in Nepal's Terai forests. Development and Change 44(1): 29-51.

Nuijten, M. 2003. Power, community and the state: the political anthropology of organisation in Mexico. London: Pluto Press. 
Paulson, S., L.L. Gezon and M.J. Watts. 2005. Politics, ecologies, genealogies. In Paulson, S. and L.L. Gezon (eds.) Political ecology across spaces, scales and social groups. New Brunswick, NJ: Rutgers University Press.

Paulson, S. and L.L. Gezon (eds.). 2005. Political ecology across spaces, scales and social groups. New Brunswick, NJ: Rutgers University Press.

Peet, R. and M.J. Watts (eds.). 2004. Liberation ecologies: environment, development, social movements. Second ed. London: Routledge.

Peluso, N.L. 2009. Rubber erasures, rubber producing rights: making racialized territories in West Kalimantan, Indonesia. Development and Change 40(1): 47-80.

Pinch, T.J. and W.E. Bijker 1984. The social construction of facts and artefacts: or how the sociology of science and the sociology of technology might benefit each other. Social Studies of Science 14(3): 399-441.

Probyn, E. 2003. The spatial imperative of subjectivity. In Anderson, K., M. Domosh, S. Pile and N. Thrift (eds.) Handbook of cultural geography. Thousand Oaks, CA: Sage: 290-299.

Rangan, H. and C.A. Kull. 2009. What makes ecology 'political'? Rethinking 'scale' in political ecology. Progress in Human Geography 33(1): 28-45.

Ribot, J.C. 2009. Authority over forests: empowerment and subordination in Senegal's democratic decentralization. Development and Change 40(1): 105-129.

Ribot, J.C. and N.L Peluso. 2003. A theory of access. Rural Sociology 68(2): 153-181.

Robbins, P. 2011. Political ecology: acritical introduction. Oxford: Wiley-Blackwell.

Richardson-Ngwenya, P. 2012. A vitalist approach to sugar-cane breeding in Barbados: in the context of the European Union sugar reform. Geoforum 43(6): 1131-1139.

Rocheleau, D.E. 2008. Political ecology in the key of policy: from chains of explanation to webs of relation. Geoforum 39(2): 716-727.

Rocheleau, D.E., B. Thomas-Slayter and E. Wangari (eds.) 1996. Feminist political ecology: global issues and local experiences. New York: Routledge.

Roth, D. 2009. Property and authority in a migrant society: Balinese irrigators in Sulawesi, Indonesia. Development and Change 40(1): 195-217.

Saar, M. 2010. Power and critique. Journal of Power 3(1): 7-20.

Schroeder, R.A. 1997. "Re-claiming" land in the Gambia: gendered property rights and environmental intervention. Annals of the Association of American Geographers 87(3): 487-508.

Schön, D., B. Sanyal and W. Mitchell. 1999. High technology and low-income communities, prospects for the positive use of advanced information technology. Cambridge MA: MIT Press.

Scott, J.C. 1985. Weapons of the weak: everyday forms of peasant resistance. New Haven: Yale University Press.

Shields, S.A. 2008. Gender: an intersectionality perspective. Sex Roles 59(5-6): 301-311.

Sikor, T., G. Auld, A.J. Bebbington, T.A. Benjaminsen, B.S. Gentry, C. Hunsberger, A.M. Izac, M.E Margulis, T. Plieninger, H. Schroeder and C. Upton. 2013. Global land governance: from territory to flow? Current Opinion in Environmental Sustainability 55: 522-527.

Sikor, T. and C. Lund. 2009. Access and property: a question of power and authority. Development and Change 40(1): $1-22$.

Slocum, R., L. Wichhart, D.E. Rocheleau and B. Thomas-Slayter (eds.). 1995. Power, process and participation: tools for change. London: ITDG Publishing.

Spencer, J. 2012. Performing democracy and violence, agonism and community, politics and not politics in Sri Lanka. Geoforum 43(4): 725-731.

Sundberg, J. 2004. Identities in the making: conservation, gender and race in the Maya Biosphere Reserve, Guatelmala. Gender, Place and Culture 11(1): 43-66.

Svarstad H., T.A. Benjaminsen and R. Overå. 2018. Power theories in political ecology. Journal of Political Ecology 25: 350-363. 
Swyngedouw, E. 2004. Social power and the urbanization of water: flows of power. Oxford: Oxford University Press.

Valentine, G. 2007. Theorizing and researching intersectionality: a challenge for feminist geography. Professional Geographer 59(1): 10-21.

Vandekerckhove, N. 2011. The state, the rebel and the chief: public authority and land disputes in Assam, India. Development and Change 42(3): 759-779.

West, P., J. Igoe and D. Brockington. 2006. Parks and peoples: the social impact of protected areas. Annual Review of Anthropology 35(1): 251-277.

Youdelis, M. 2013. The competitive (dis)advantages of ecotourism in Northern Thailand. Geoforum 50: 161171.

Zimmerer, K.S. 2000. The reworking of conservation geographies: nonequilibrium landscapes and naturesociety hybrids. Annals of the Association of American Geographers 90(2): 356-369. 